\title{
GAMBARAN REINJURY ANXIETY PADA ATLET MAHASISWA UNPAD: STUDI KUALITATIF
}

\author{
Nabilla Fazahra Gunawan, Putu Satwika Arya Govinda, Sukmayanti, Retno Hanggarani Ninin \\ Fakultas Psikologi, Universitas Padjadjaran \\ J1. Raya Bandung Sumedang KM.21 Kabupaten Sumedang, Jawa Barat 45363 \\ Email: nabilla16004@mail.unpad.ac.id
}

\begin{abstract}
ABSTRAK. Cedera menjadi suatu konsekuensi negatif yang pasti dihadapi setiap atlet. Cedera dapat menimbulkan berbagai reaksi diantaranya reaksi kognitif, reaksi somatis, dan reaksi emosi. Reinjury anxiety menjadi salah satu aspek psikologis yang dapat muncul akibat terjadinya cedera. Penelitian ini bertujuan untuk mengetahui bagaimana gambaran reinjury anxiety yang terjadi pada atlet mahasiswa. Pendekatan yang digunakan adalah pendekatan kualitatif. Pemilihan partisipan dilakukan dengan purposive sampling, dimana partisipan yang diambil adalah partisipan memiliki kriteria: (1) Atlet mahasiswa, (2) Pernah mengalami cedera, (3) Melakukan tahapan medis, dan (4) Setelah melakukan tahapan medis diperbolehkan kembali untuk melakukan olahraga yang sama. Partisipan dalam penelitian ini adalah 6 atlet mahasiswa yang terdiri atas 3 atlet mahasiswa yang berasal dari cabang olahraga futsal dan 3 atlet mahasiswa yang berasal dari cabang olahraga voli. Metode yang digunakan adalah metode kualitatif melalui wawancara. Hasil dari penelitian ini menunjukan bahwa gejala reinjury anxiety muncul pada para partisipan penelitian baik dalam bentuk gejala somatis, kognitif, maupun emosi dimana gejala kognitif menjadi gejala yang paling sering dirasakan oleh partisipan.
\end{abstract}

Keywords: Reinjury anxiety, cedera, olahraga

\section{DESCRIPTION OF REINJURY ANXIETY IN UNPAD'S STUDENT ATHLETES: A QUALITATIVE STUDY}

ABSTRACT. Injury becomes one of negative consequences of sports that every athletes faced. We cannot deny that there are many psychological aspects that are involved when injury occur. Reinjury anxiety is one of psychological aspects that arises due to the injury. This study aims to determine the description of reinjury anxiety that occurs in student athletes. The approach that used in this study is a qualitative approach. The selection of participants was done by purposive sampling, where participants were taken as participants who had the criteria: (1) Student athletes, (2) Have experienced injuries, (3) Perform medical stages, and (4) After doing medical stages are allowed to do the same sports. The participants were 6 student athletes consisting of 3 student athletes from futsal and 3 student athletes from volleyball. Data are taken by interviewing the participants. The results of this study indicate that reinjury anxiety symptoms appear in all participants both in the form of somatic, cognitive, and emotional symptoms, where the cognitive symptoms are the most common symptom that felt by the participants.

Keywords: Reinjury anxiety, Sports, Injury

\section{PENDAHULUAN}

Olahraga sebagai aktivitas yang menggunakan fisik dan melibatkan gerakan-gerakan tertentu memungkinkan terjadinya masalah pada bagian tubuh tertentu. Dengan kata lain, olahraga memiliki risiko terjadinya cedera yang akan bervariasi jenis dan keparahannya antara satu olahraga dengan olahraga lainnya. Terjadinya cedera dapat menghentikan seseorang untuk melakukan olahraga tersebut selama beberapa waktu.

Masalah belum tentu selesai dengan penyembuhan secara fisik. Seringkali performa seorang atlet antara sebelum dan sesudah cedera dapat berbeda. Tak jarang performanya menjadi menurun setelah cedera. Trauma, kepercayaan diri yang menurun, hingga ketakutan akan terjadinya lagi cedera dapat berpengaruh terhadap performanya bahkan setelah cedera itu sembuh. Tidak menutup kemungkinan, cedera ini dapat mengakhiri karir seorang atlet.

Sebagaimana atlet pada umumnya, atlet maha- siswa juga dapat terkena cedera sebagai konsekuensi keikutsertaannya pada kegiatan olahraga. Cedera pada atlet mahasiswa dapat menjadi masalah serius. Hal ini dikarenakan atlet mahasiswa harus menyeimbangkan performa akademik dan performa di lapangan sehingga terjadinya cedera dapat menjadi stressor tambahan (Etzel, 2006).

Menurut Putukian (2016), ditemukan respon yang berbeda-beda terhadap kejadian cedera. Respon-respon tersebut berentang dari respon yang normal hingga respon-respon problematik. Respon-respon normal diantaranya adalah perasaan sedih, perasaan terisoloasi, mudah tersinggung, berkurangnya motivasi, kemarahan, frustasi, hingga perubahan nafsu makan, dan gangguan tidur. Adapun respon-respon normal tersebut apabila tidak ditangani dengan baik dapat menjadi respon problematik, misalnya emosi sedih dapat menjadi gejala depresi atau penurunan motivasi dapat mengarah kepada timbulnya respon apati. Oleh karena itu penting bagi pelatih maupun pembina atlet mahasiswa untuk men- 
genali reaksi-reaksi yang muncul ketika terjadinya cedera untuk mencegah atau menanggulangi kemunculan respon problematik pada atlet yang bersangkutan.

Berbagai faktor telah diungkap oleh penelitian sebelumnya, tentang faktor-faktor psikologis yang timbul pada seorang atlet selepas cedera. Salah satu fenomena psikologis yang timbul pada seseorang adalah adanya kecemasan untuk mengalami cedera itu kembali, atau yang disebut sebagai reinjury anxiety. (Walker \& Tratcher, 2011 dalam Wadey at al, 2014). Reinjury anxiety secara spesifik mencakup adanya respon emosi negatif yang disertai dengan gejala-gejala kognitif dan somatis. Gejala-gejala tersebut meningkat ketika adanya kemungkinan untuk cedera terjadi lagi setelah cedera yang sama dan pada bagian tubuh yang sama (Walker \& Tratcher, 2011 dalam Wadey at al, 2014).

Penelitian lain yang dilakukan oleh Walker et al (2002) mencoba untuk melihat bagaimana atlet mengantisipasi adanya kemungkinan untuk cedera kembali dan membayangkan kejadian itu kembali. Mereka juga dilaporkan mengalami bayangan-bayangan akan terjadinya cedera itu kembali dalam berbagai situasi.

Ditinjau dari keterlibatan salah satu aspek psikologis yang muncul setelah cedera yang mana adalah reinjury anxiety, menarik bagi peneliti untuk mengetahui gambaran mengenai reinjury anxiety yang ada pada populasi atlet mahasiswa.

Menurut Council of Europe (2001, dalam Arvinen-Barrow \& Walker, 2013), olahraga adalah semua bentuk dari aktivitas fisik dengan partisipasi sederhana ataupun terorganisir yang bertujuan untuk mengekspresikan atau meningkatkan kesehatan fisik dan mental well-being, membentuk relasi sosial atau mendapatkan suatu hasil dalam kompetisi.

Keikutsertaan individu pada olahraga seringkali menempatkan individu dibawah tekanan fisik dan psikologis yang besar serta stress yang memungkinkan akan adanya hasil negatif seperti cedera (Arvinen-Barrow, 2014). Cedera adalah salah satu konsekuensi negatif yang mungkin terjadi ketika melakukan suatu aktivitas olahraga.

Selain menimbulkan rasa sakit fisik, cedera juga dapat memicu reaksi kognitif dan emosional. Respon kognitif yang jamak ditemui pada atlet yang mengalami cedera antara lain menurunnya self-esteem, mencoba membuat atribusi terkait penyebab cederanya (entah internal seperti kurangnya pemanasan atau eksternal seperti kondisi lapangan), dan memikirkan penggunaan strategi coping. Tanggapan emosional yang dilaporkan secara umum ketika terjadi cedera atletik antara lain ketidakpercayaan, ketakutan, kemarahan, dan ketidakmampuan untuk mengatasi rehabilitasi cedera yang lama dan pembatasan aktivitas yang dikenakan oleh cedera (Smith, Scott, \& Wiese, 1990; dalam (Walker, Thatcher, Lavallee, \& Golby, 2004). Rotella \& Heyman, (1993) juga mencatat respon emosional lain seperti perasaan terisolasi atau kesepian, kemarahan atau kebencian, depresi, dan kecemasan. Dalam penelitian Putukian (2015) ditemukan respon emosional terhadap cedera yang dihadapi atlet mahasiswa diantaranya adalah kesedihan, perasaan terisolasi, irritation, berkurangnya motivasi, rasa marah, frustasi, perubahan nafsu makan, dan tidur yang terganggu.

Dampak tidak menyenangkan tersebut memungkinkan terjadinya kecemasan atlet terkait dengan cedera. Walaupun semua atlet mencoba menghindari cedera, hampir semua atlet dapat mengalami cedera sementara ataupun secara permanen yang nantinya akan berpengaruh pada partisipasinya dalam olahraga kembali (Taylor \& Taylor, 1997 dalam Arvinen-Barrow, 2014)

Kecemasan atau anxiety adalah emosi yang dicirikan dengan ketakutan dan gejala ketegangan somatik di mana individu mengantisipasi bahaya, malapetaka, atau ketidak beruntungan (APA, 2015). Ford, Ildefonso, Jones, \& Arvinen-Barrow (2017) mengungkapkan anxiety adalah keadaan psikologis yang tidak menyenangkan sebagai reaksi terhadap stres yang dipersepsikan terkait dengan pengerjaan tugas di bawah tekanan. Salah satu kecemasan yang umum terjadi pada atlet atau orang yang berolahraga adalah sport injury anxiety atau kecenderungan untuk merespon situasi olahraga di mana situasi tersebut memungkinkan terjadinya cedera dengan kecemasan secara kognitif atau somatik (Kleinert, 2002). Kecemasan ini dapat terjadi baik pada orang yang pernah maupun belum pernah mengalami cedera.

Lebih spesifik lagi, pada atlet yang pernah mengalami cedera adalah reinjury anxiety yang tak jarang menghambat kembalinya atlet untuk melakukan olahraga bahkan setelah cedera tersebut sembuh secara fisik. Menurut Hagglund, Walden, Bahr, \& Ekstrand (2005), reinjury adalah istilah yang merujuk pada cedera sejenis yang terjadi di lokasi yang sama dengan cedera yang pernah terjadi. Sementara reinjury anxiety adalah respon emosi negatif, dengan gejala kognitif (seperti pikiran negatif \& images) dan gejala somatis (seperti merasakan mual dan ketegangan), yang muncul ketika adanya kemungkinan untuk kembali terjadinya cedera sejenis di lokasi tubuh yang sama (Walker \& Thatcher, 2012). Temuan empiris lainnya mendapati anteseden dari reinjury anxiety adalah waktu operasi setelah cedera, kurangnya percaya diri dari bagian tubuh yang cedera, melakukan keterampilan yang sama dalam situasi yang sama, dan adanya kekhawatiran adanya penurunan potensial (e.g.,Ardem, Taylor, Feller, \& Webster, 2012; 
Bianco, Malo, \& Orlick, 1999; Christakou, Zervas, Stavrou, \& Psychountaki, 2011; Podlog \& Eklund, 2006 dalam Wadey et al., 2014).

Studi korelasi dan laporan kualitatif sebelumnya mengungkapkan bahwa reinjury anxiety menjadi salah satu alasan yang paling sering dikutip untuk mengurangi atau berhenti berpartisipasi dalam olahraga (e.g., Ardem et al., 2012, 2011; Heijne, Axelsson, Werner, \& Biguet, 2008; Kvist, Ek, Sporrstedt, \& Good, 2005; Tripp et al., 2007 dalam (Wadey et al., 2014). Untuk atlet yang kembali pada kompetisi, reinjury anxiety dapat dimanifestasi melalui beberapa cara seperti perasaan ragu, menahan diri dan pemberian usaha yang lebih sedikit dibandingkan dengan usaha maksimalnya yang mana semua ini dapat berdampak negatif terhadap performa dari olahraga itu sendiri. (e.g., Ardem et al., 2012; Evans, Hardy, \& Fleming 2000; Gould, Udry, Bridges, \& Beck, 1997; Johnston \& Carroll, 1998 dalam Wadey et al., 2014). Mereka yang memiliki reinjury anxiety lebih besar adalah atlet yang baru mengalami cedera (Callen, 2015).

Walker et al. (2004) mengemukakan bahwa reinjury anxiety berbeda dari sports performance anxiety yang berhubungan dengan kegagalan untuk mencapai kemampuan tertentu tanpa implikasi dari cedera. menemukan bahwa atlet yang mengalami cedera akan lebih mengantisipasi kemungkinan untuk kembali menderita cedera dan membayangkan kembali saat-saat terjadinya cedera daripada lebih mengantisipasi resiko-resiko lain yang mungkin akan menyebabkan cedera kembali. Mereka juga dilaporkan mengalami bayangan-bayangan akan terjadinya cedera tersebut pada berbagai situasi klinis maupun olahraga yang spesifik.

Dalam berbagai penelitian mengenai hal ini, terdapat tumpang tindih antara pemakaian istilah reinjury anxiety (kecemasan akan terjadinya kembali cedera) dan fear of reinjury (ketakutan akan terjadinya kembali cedera). Hackfort dan Schwenkmezger dalam Walker, Thatcher, \& Lavallee (2010) menyatakan bahwa ketakutan (fear) adalah mekanisme biologis dasar sementara kecemasan (anxiety) mengandung elemen-elemen yang berbeda seperti elemen kognitif dan somatis serta diasosiasikan dengan proses belajar dan proses sosial. Ketakutan didefinisikan berhubungan dengan stimulus yang spesifik dan terasosiasi dengan bahaya yang jelas sementara kecemasan berhubungan dengan antisipasi dan bayang-bayang akan sesuatu yang ambigu dan belum jelas. Walker, Thatcher, Lavallee, \& Golby (2004) berpendapat bahwa dalam konteks reinjury, istilah reinjury anxiety lebih tepat ketimbang fear of reinjury. Anxiety atau kecemasan lebih kepada perasaan mengenai apa yang mungkin terjadi ketimbang respon terhadap situasi yang jelas-jelas membangkitkan perasaan takut. Kekhawatiran akan terjadinya kembali cedera disebut-sebut mirip dengan ketakutan untuk bergerak/ reinjury atau disebut kinesiophobia dimana atlet yang melaporkan ketakutan akan reinjury juga menunjukkan peningkatan kinesiophobia (Hsu, Meierbachtol, George, \& Chmielewski, 2017).

Kebanyakan atlet mengalami kecemasan ini ketika menjalani rehabilitasi ketimbang saat kembali terjun berolahraga selepas cedera. Hal ini mendukung temuan Taylor \& Taylor (dalam Walker et al., 2004) yang menyatakan bahwa ketakutan akan kembali cedera terjadi selama persiapan untuk kembali ke olahraga dan karena adanya rehabilitasi yang tidak lengkap atau tidak efektif. Temuan empiris dari Walker et al. (2004) juga menemukan bahwa ketakutan akan kembali cedera adalah stressor utama bagi $57.1 \%$ anggota tim ski Amerika Serikat yang pernah cedera selama masa rehabilitasi mereka.

Cupal \& Brewer (2001, dalam Wadey et al., 2014) menemukan bahwa reinjury anxiety dapat memiliki konsekuensi negatif terhadap performa atlet yang sudah kembali berkompetisi dalam kegiatan olahraga. Reinjury anxiety dapat meningkatkan kesadaran atlet terhadap limitasi terhadap performa mereka ketika berolahraga (Wadey, Podlog, Hall, Hamson-utley, et al., 2014).

Heil (1993) berpendapat bahwa ketakutan akan terjadinya cedera selalu ada pada diri setiap atlet. Hal ini dapat memberikan perubahan-perubahan fisiologis maupun psikologis yang dapat memengaruhi performa atlet dan meningkatkan risiko terjadinya cedera. Adapun perubahan fisiologis yang dapat terjadi misalnya ketegangan otot yang meningkat, terjadinya arousal yang berlebihan, meningkatnya sensasi fisik dari sumber cedera, dan berkurangnya keseimbangan (Heil, 1993). Sementara perubahan psikologis yang terjadi antara lain berkurangnya keengganan untuk menggunakan bagian tubuh yang menjadi lokasi cedera (misalnya menurunkan frekuensi penggunaan kaki kiri untuk menendang bola setelah cedera pergelangan kaki kiri), menurunnya konsentrasi dan fokus, menurunnya kepercayaan diri, dan meningkatnya kepekaan terhadap rasa sakit (Taylor \& Taylor, 1997; Heil, 1993). Pargman dalam Walker, Thatcher, Lavallee, dan Golby (2004) menyatakan bahwa kecemasan akan reinjury dapat memengaruhi performa atlet sekembalinya ia berkompetisi. Persepsi ini memengaruh performa melalui penurunan efisiensi biomekanis ketika melakukan skill tertentu, penggunaan energi yang buruk, dan penurunan atensi (Walker, Thatcher, Lavallee, \& Golby, 2004).

Implikasi potensial dari adanya reinjury anxiety itu diantaranya adalah kesiapan performa \& psikologis individu ketika sedang rehabilitasi, ketika kembali berlatih, dan kembali berkompetisi dan kemungkinan pen- 
ingkatan akan adanya cedera kembali yang sebenarnya (Walker, Thatcher, \& Lavallee, 2010).

\section{METODE}

Penelitian ini adalah penelitian dengan pendekatan kualitatif. Pemilihan partisipan dilakukan dengan purposive sampling, dimana partisipan yang diambil adalah (1) atlet mahasiswa, (2) Pernah mengalami cedera, (3) Melakukan tahapan medis, dan (4) Setelah melakukan tahapan medis diperbolehkan kembali untuk melakukan olahraga yang sama. Adapun purposive sampling yang dilakukan adalah stratified purposive sampling dimana partisipan yang dicari adalah partisipan dari mahasiswa yang mengikuti olahraga futsal yang mewakili olahraga yang memungkinkan kontak fisik dan mahasiswa yang mengikuti olahraga voli yang mewakili olahraga tanpa kontak fisik dengan lawan.

Partisipan dalam penelitian ini berjumlah 6 orang dimana 3 orang berasal dari cabang olahraga futsal, dan 3 lainnya berasal dari cabang olahraga voli. Setiap partisipan mengalami cedera pada bagian tubuh yang berbeda-beda. Ketika cedera tersebut terjadi, semua partisipan mendapatkan perawatan medis dan mendapatkan diagnosis yang berbeda-beda pula. Bahkan, partisipan 05 dan 06 melakukan operasi pada bagian tubuh yang cedera akibat olahraga tersebut, sedangkan empat partisipan lainnya tidak sampai kepada tahap operasi. Waktu yang dibutuhkan untuk kembali pulih pun berbeda-beda pada setiap partisipan, berdurasi pada rentang antara 1 - 8 bulan. Setelah mendapatkan diagnosis dari dokter, kemudian menjalani rehabilitasi, keenam partisipan diperbolehkan untuk kembali melakukan olahraga kembali. Pengambilan data dilakukan dengan interviu semi-struktur.

Setelah data didapatkan dilakukan analisis data dengan metode tematik yang mengelompokkan serangkaian teks yang bermakna sama. Koding tersebut didasarkan pada tiga gejala yang ada ketika seseorang mengalami cedera hingga ia kembali berolahraga yaitu gejala emosi, gejala kognitif, dan gejala somatis. Verifikasi terhadap pengkodingan tersebut dilakukan dengan peer review yang dilakukan oleh tiga orang interrater. Interrater memberikan pandangannya dengan merujuk pada pengkodingan berdasarkan tiga jenis gejala reinjury anxiety menurut Wadey et al., (2014). Ketiga gejala tersebut adalah gejala emosi, gejala kognitif, dan gejala somatis. Kemunculan ketiga gejala tersebut dapat dilihat pada tiga periode yang berbeda, yakni ketika terjadinya cedera, ketika rehabilitasi, dan ketika kembali berolahraga. Setelah itu, peneliti melakukan revisi koding dengan apa yang sudah interrater coder berikan. Setelah diskusi, maka didapatkan kesepakatan data sesuai den- gan persetujuan kedua belah pihak (interrater-coder agreement).

\section{HASIL DAN PEMBAHASAN}

Dari hasil wawancara kepada keenam partisipan, terdapat 116 data tunggal yang berhasil dikoding. Kode-kode paling banyak ditemukan pada kategori gejala kognitif sebanyak 56 data tunggal. Setelah itu, kategori gejala emosi sebanyak 34 data tunggal dan kategori gejala somatis sebanyak 26 data tunggal. Sebaran setiap gejala berbeda-beda pada setiap waktu (ketika cedera, rehabilitasi, dan ketika kembali berolahraga). Ketika cedera, gejala kognitif menjadi gejala terbanyak dengan 12 data tunggal, diikuti gejala somatis sebanyak 9 data tunggal dan gejala emosi sebanyak 6 data tunggal. Pada tahap rehabilitasi, gejala terbanyak adalah gejala emosi dengan 16 data tunggal, gejala kognitif 18 data tunggal, dan gejala somatis sebanyak 9 data tunggal. Sedangkan pada tahap ketika kembali berolahraga, gejala terbanyak adalah gejala kognitif sebanyak 26 data tunggal, gejala emosi sebanyak 12 data tunggal, dan gejala somatis sebanyak 8 data tunggal. Gejala-gejala tersebut akan dibahas lebih lanjut menurut kemunculannya pada tiga periode waktu yang berbeda yaitu pada saat terjadinya cedera, rehabilitasi, dan ketika kembali berolahraga.

Serupa dengan apa yang dikatakan oleh Smith, Scott, \& Wiese (1990, dalam Walker et al., 2004) bahwa reaksi emosional yang dilaporkan secara umum ketika terjadi cedera atletik antara lain ketidakpercayaan, ketakutan, kemarahan, dan ketidakmampuan untuk mengatasi rehabilitasi cedera yang lama dan pembatasan aktivitas yang dikenakan oleh cedera ditemukan pada partisipan. Pada Tabel 2 menunjukkan adanya gejala emosi, gejala kognitif, dan juga somatis terhadap apa yang dirasakan oleh atlet ketika cedera.

Reaksi emosi negatif ditemukan pada partisipan 02, 03, 05, dan 06 seperti reaksi sedih, kaget, dan takut. Sedangkan partisipan 01 dan 04 tidak merasakan emosi apapun ketika cedera. Selain itu, adapun emosi-emosi yang muncul dikarenakan adanya gejala kognitif. Dapat dilihat pada partisipan 02, bahwa perasaan khawatir muncul karena partisipan berpikiran apakah dirinya dapat berkontribusi lagi untuk timnya atau tidak. Perasaan khawatir ini juga muncul di partisipan 01 ketika partisipan berpikir apakah cedera yang di alaminya akan berpengaruh akan penurunan performanya. Ketakutan akan terjadinya cacat pada dirinya sendiri akibat cedera dirasakan oleh partisipan 05 .

Gejala kognitif lainnya pun muncul pada partisipan 01, 02 dan 06 dimana partisipan berpikir apakah dirinya dapat berolahraga kembali atau tidak. Selain itu, adanya pemikiran bahwa cedera yang dialaminya ketika 
itu tidak akan parah terjadi pada partisipan 01, 02 dan 04.

Gejala somatis yang berupa reaksi fisik ketika cedera muncul di setiap partisipan. Hanya partisipan 01 yang merasakan bahwa reaksi fisik yang terjadi dikarenakan adanya kecemasan terhadap cederanya tersebut. Partisipan lainnya menyatakan bahwa gejala-gejala somatis seperti kaki yang mati rasa, tidak dapat berlari, nyeri, kaki sakit, dan badan seperti patah diakibatkan langsung karena bagian tubuh yang cederanya itu sendiri. untuk kembali ke olahraga dan karena adanya rehabilitasi yang tak lengkap atau tidak efektif. Namun berdasarkan data penelitian yang didapat, bahwa bayang-bayang akan cedera kembali hanya muncul pada satu partisipan yakni partisipan 01 yang terbayang akan kembali cedera saat membayangkan dirinya melompat ketika bermain lagi. Reaksi serupa lebih banyak muncul pada saat atlet kembali berolahraga bukan saat rehabilitasi.

Adapun reaksi-reaksi kognitif yang dipikirkan partisipan antara lain konsentrasi untuk segera sembuh dan

\begin{tabular}{|l|l|l|l|}
\hline \multicolumn{4}{|l|}{ Tabel 1 } \\
Partisipan & Waktu Cedera & Diagnosis Medis & Durasi rehabilitasi \\
\hline 01/L/Voli & $\begin{array}{l}\text { Agustus 2017 } \\
\text { Desember 2017 } \\
\text { Agustus 2018 }\end{array}$ & $\begin{array}{l}\text { Urat bahu kejepit \& geser } \\
\text { Lutut urat \& sendiri bermasalah }\end{array}$ & Satu bulan setengah \\
\hline 02/P/Voli & Januari 2017 & Radang sendi panggul & Tiga bulan \\
\hline 03/P/Voli & Februari 2017 & Pinggang sebelah kanan atas bengkok & Tiga bulan \\
\hline 04/L/Futsal & November 2017 & Ligamen paha kanan putus & Delapan bulan \\
\hline 05/L/Futsal & Desember 2017 & $\begin{array}{l}\text { Cedera robek Meniskus lutut kanan dan } \\
\text { cedera MCL }\end{array}$ & Dua bulan tiga minggu \\
\hline 06/P/Futsal & November 2017 & $\begin{array}{l}\text { Ligament PCL hampir putus dan pera- } \\
\text { dangan meniskus }\end{array}$ & Delapan bulan \\
\hline
\end{tabular}

\begin{tabular}{|c|c|c|c|c|c|c|}
\hline \multicolumn{7}{|c|}{$\begin{array}{c}\text { Tabel } 2 \\
\text { Gejala Ketika Cedera }\end{array}$} \\
\hline $\begin{array}{l}\text { Kategori/ } \\
\text { Partisipan }\end{array}$ & Partisipan 01 & Partisipan 02 & Partisipan 03 & Partisipan 04 & Partisipan 05 & Partisipan 06 \\
\hline Gejala Emosi & - Tidak ada & - Sedih & - Kaget & - Tidak ada & - Takut & - Takut \\
\hline Gejala Kognitif & $\begin{array}{l}\text { - Berpikir dapat } \\
\text { bermain lagi } \\
\text { atau tidak } \\
\text { - Mengira } \\
\text { cederanya tidak } \\
\text { parah } \\
\text { - Kekhawa- } \\
\text { tiran akan } \\
\text { penurunan } \\
\text { performa }\end{array}$ & $\begin{array}{l}\text { - Mengira cede- } \\
\text { ra tidak parah } \\
\text { - Khawatir tidak } \\
\text { dapat berkontri- } \\
\text { busi lagi untuk } \\
\text { tim }\end{array}$ & $\begin{array}{l}\text { - Berpikir dapat } \\
\text { bermain lagi } \\
\text { atau tidak }\end{array}$ & $\begin{array}{l}\text { - Mengira cede- } \\
\text { ra tidak parah }\end{array}$ & - Takut cacat & $\begin{array}{l}\text { - Berpikir dapat } \\
\text { bermain lagi } \\
\text { atau tidak }\end{array}$ \\
\hline Gejala Somatis & $\begin{array}{l}\text { - Gejala so- } \\
\text { matis muncul } \\
\text { karena kece- } \\
\text { masan }\end{array}$ & $\begin{array}{l}\text { - Gejala somatis } \\
\text { muncul karena } \\
\text { cedera }\end{array}$ & $\begin{array}{l}\text { - Gejala somatis } \\
\text { muncul karena } \\
\text { cedera }\end{array}$ & $\begin{array}{l}\text { - Gejala somatis } \\
\text { muncul karena } \\
\text { cedera }\end{array}$ & $\begin{array}{l}\text { - Gejala so- } \\
\text { matis muncul } \\
\text { karena cedera }\end{array}$ & $\begin{array}{l}\text { - Gejala somatis } \\
\text { muncul karena } \\
\text { cedera }\end{array}$ \\
\hline
\end{tabular}

Selain gejala yang timbul saat cedera, terdapat juga gejala yang timbul saat rehabilitasi. Berdasarkan temuan pada penelitian sebelumnya yang dilakukan oleh Taylor \& Taylor (dalam Walker et al., 2004) menyatakan bahwa ketakutan akan kembali cedera terjadi selama persiapan kembali berolahraga secara normal, memikirkan efek samping yang mungkin terjadi dari rehabilitasi, proses bedah yang akan dijalani, menyayangkan dirinya tidak bisa berkompetisi lagi, lega karena proses rehabilitasi tidak semahal yang dikira, menyesali mengapa harus di- 
rinya yang mengalami cedera, menjadi lebih termotivasi saat kembali berolahraga, mengkhawatirkan penurunan performa, dan memikirkan bahwa dirinya harus lebih berhati-hati saat kembali bermain.

Sementara emosi yang dirasakan ketika menjalani rehabilitasi adalah sedih, takut, sakit hati, dan merasa tidak enak ketika digantikan orang lain di tim. Adapun respon lain yang muncul adalah merasa iri pada mereka yang bisa bermain. Gejala somatis yang dirasakan oleh partisipan kebanyakan adalah respon akibat dari cedera yang dialami dan peningkatan kepekaan terhadap rasa sakit. Adapun respon somatis akibat reinjury anxiety yang muncul adalah pada partisipan 01 yang menjadi kurus karena stress pada cedera yang dialami.

Gejala-gejala reinjury anxiety juga muncul saat atlet kembali berolahraga. Dari hasil wawancara kepada 6 partisipan, tanggapan emosional yang dilaporkan oleh Smith, Scott, \& Wiese dalam Walker et al., 2004) juga muncul pada mereka ketika terjadi cedera maupun ketika menjalani rehabilitasi. Respon emosi tersebut antara lain ketakutan (muncul pada semua partisipan) dan pembatasan aktivitas yang dikenakan oleh cedera (semua partisipan). Sementara kemarahan tidak muncul pada partisipan penelitian ini. Adapun respon lain

\begin{tabular}{|c|c|c|c|c|c|c|}
\hline \multicolumn{7}{|c|}{$\begin{array}{c}\text { Tabel } 3 \\
\text { Gejala Ketika Rehabilitasi }\end{array}$} \\
\hline $\begin{array}{l}\text { Kategori/ } \\
\text { Partisipan }\end{array}$ & Partisipan 01 & Partisipan 02 & Partisipan 03 & Partisipan 04 & Partisipan 05 & Partisipan 06 \\
\hline Gejala Emosi & - Takut & $\begin{array}{l}\text { - Takut } \\
\text { - Sedih }\end{array}$ & - Takut & $\begin{array}{l}\text { - Khawatir } \\
\text { - Cemas } \\
\text { - Takut }\end{array}$ & - Khawatir & - Sedih \\
\hline Gejala Kognitif & $\begin{array}{l}\text { - Adanya } \\
\text { keinginan untuk } \\
\text { sembuh } \\
\text { - Terbayang diri } \\
\text { akan cedera lagi }\end{array}$ & $\begin{array}{l}\text { - Adanya } \\
\text { keinginan untuk } \\
\text { sembuh } \\
\text { - Merepotkan } \\
\text { orang lain }\end{array}$ & $\begin{array}{l}\text { - Meren- } \\
\text { cana-kan hal-hal } \\
\text { untuk menang- } \\
\text { gulangi cedera }\end{array}$ & $\begin{array}{l}\text { - Takut cacat, } \\
\text { mengkhatir-kan } \\
\text { biaya pengo- } \\
\text { batan }\end{array}$ & $\begin{array}{l}\text { - Mengkha- } \\
\text { watir-kan } \\
\text { penurunan } \\
\text { performa }\end{array}$ & $\begin{array}{l}\text { - Mengkhawa- } \\
\text { tir-kan biaya } \\
\text { pengobatan }\end{array}$ \\
\hline Gejala Somatis & $\begin{array}{l}\text { - Karena kece- } \\
\text { masan (menjadi } \\
\text { kurus karena } \\
\text { stress) }\end{array}$ & $\begin{array}{l}\text { - Peningkatan } \\
\text { pain awareness }\end{array}$ & $\begin{array}{l}\text { - Reaksi sakit } \\
\text { akibat cederanya }\end{array}$ & $\begin{array}{l}\text { - Reaksi sakit } \\
\text { akibat ceder- } \\
\text { anya }\end{array}$ & - Tidak ada & $\begin{array}{l}\text { - Reaksi sakit } \\
\text { akibat ceder- } \\
\text { anya }\end{array}$ \\
\hline
\end{tabular}

\begin{tabular}{|c|c|c|c|c|c|c|}
\hline \multicolumn{7}{|c|}{$\begin{array}{c}\text { Tabel } 4 \\
\text { Gejala Saat Kembali Berolahraga }\end{array}$} \\
\hline $\begin{array}{l}\text { Kategori/ } \\
\text { Partisipan }\end{array}$ & Partisipan 01 & Partisipan 02 & Partisipan 03 & Partisipan 04 & Partisipan 05 & Partisipan 06 \\
\hline Gejala Emosi & - Takut & $\begin{array}{l}\text { - Takut, kha- } \\
\text { watir }\end{array}$ & - Cemas & - Takut, sedih & - Takut & - Sedih \\
\hline Gejala Kognitif & $\begin{array}{l}\text { - Merencanakan } \\
\text { hal-hal untuk } \\
\text { menanggu-langi } \\
\text { cedera, terbayang } \\
\text { cedera terjadi } \\
\text { pada orang lain, } \\
\text { terbayang cedera } \\
\text { kembali terjadi } \\
\text { pada diri sendiri, } \\
\text { khawatir akan } \\
\text { penurunan per- } \\
\text { forma }\end{array}$ & $\begin{array}{l}\text { - Terbayang } \\
\text { cedera kembali } \\
\text { terjadi pada } \\
\text { diri sendiri, } \\
\text { merencana-kan } \\
\text { hal-hal untuk } \\
\text { menanggu-lan- } \\
\text { gi cedera, } \\
\text { mengkhawatir- } \\
\text { kan penuruan } \\
\text { performa }\end{array}$ & $\begin{array}{l}\text { - Meren- } \\
\text { cana-kan hal-hal } \\
\text { untuk menang- } \\
\text { gu-langi cedera, } \\
\text { terbayang ced- } \\
\text { era terjadi pada } \\
\text { orang lain }\end{array}$ & $\begin{array}{l}\text { - Terbayang } \\
\text { cedera terjadi } \\
\text { pada orang lain }\end{array}$ & $\begin{array}{l}\text { - Terbayang } \\
\text { cedera terjadi } \\
\text { pada orang } \\
\text { lain, terbayang } \\
\text { cedera kembali } \\
\text { terjadi pada } \\
\text { diri sendiri }\end{array}$ & $\begin{array}{l}\text { - Khawa- } \\
\text { tir akan } \\
\text { penurunan } \\
\text { performa } \\
\text { - Menghindari } \\
\text { penggunaan } \\
\text { kaki yang } \\
\text { cedera untuk } \\
\text { tumpuan }\end{array}$ \\
\hline Gejala Somatis & $\begin{array}{l}\text { - Karena kecema- } \\
\text { san (jantung ber- } \\
\text { degup cepat saat } \\
\text { akan olahraga) }\end{array}$ & $\begin{array}{l}\text { - Reaksi tubuh } \\
\text { akibat ceder- } \\
\text { anya }\end{array}$ & - Tidak ada & $\begin{array}{l}\text { - Reaksi tubuh } \\
\text { akibat ceder- } \\
\text { anya }\end{array}$ & $\begin{array}{l}\text { - Mening- } \\
\text { katnya pain } \\
\text { awareness }\end{array}$ & $\begin{array}{l}\text { - Karena kece- } \\
\text { mas-an (tubuh } \\
\text { jadi ragu-ragu } \\
\text { untuk bergerak) }\end{array}$ \\
\hline
\end{tabular}


yang ditemukan pada partisipan penelitian ini adalah emosi sedih (partisipan 02), kaget (partisipan 03), sakit hati (partisipan 01), iri pada mereka yang bisa bermain (partisipan 01), khawatir (partisipan 04 dan 05), cemas (partisipan 04), serta waswas (partisipan 04).

Menurut Heil (1993), ada perubahan psikologis yang terjadi pada atlet yang mengalami cedera yakni menurunnya konsentrasi dan fokus, menurunnya kepercayaan diri, dan meningkatnya kepekaan terhadap rasa sakit. Kepekaan terhadap rasa sakit ini juga terjadi pada partisipan 05 , dimana saat ia kembali berolahraga ia merasa bahwa bagian tubuh yang mengalami cedera menjadi mudah terasa sakit. Namun untuk perubahan psikologis seperti menurunnya konsentrasi dan fokus serta menurunnya kepercayaan diri tidak muncul pada atlet yang menjadi partisipan dalam penelitian ini.

Beberapa temuan empiris menunjukkan bahwa dampak dari reinjury anxiety ini adalah kurangnya kepercayaan diri untuk menggunakan bagian tubuh yang cedera, khawatir ketika melakukan gerakan yang sama dalam situasi yang sama ketika cedera terjadi, dan adanya kekhawatiran adanya penurunan potensial. Pada penelitian ini ditemukan bahwa terdapat 2 partisipan yang menghindari penggunaan bagian tubuh yang terkena cedera ketika kembali berolahraga setelah sembuh. Mereka antara lain partisipan 04 yang tidak menggunakan kaki kanan untuk menendang maupun mengoper lagi dan partisipan 06 yang tidak menggunakan kaki kirinya untuk tumpuan. Untuk kekhawatiran melakukan gerakan yang sama terjadi pada beberapa partisipan seperti partisipan 01 yang terbayang akan kembali cedera ketika melompat dan partisipan 05 yang menghindari benturan karena khawatir akan kembali cedera. Hal ini dapat dimaknai pula sebagai perilaku menghindar sebagai antisipasi agar tidak terjadi cedera kembali (Cassidy, 2006). Sementara kekhawatiran akan penurunan performa terjadi pada partisipan 01, 03, 05, 06 .

Bayang-bayang cedera terdahulu yang tiba-tiba muncul, bayang-bayang akan cedera di posisi yang sama dan lokasi tubuh yang sama juga ditemukan pada partisipan 01, 02, dan 05. Hal ini selaras dengan apa yang dikatakan Hackfort dan Schwenkmezger dalam Walker, Thatcher, \& Lavallee (2010) yang menyatakan bahwa kecemasan berhubungan dengan antisipasi dan bayangbayang akan sesuatu yang ambigu dan belum jelas. Bayang-bayang ini muncul dengan sendirinya tanpa ada sesuatu yang memicunya dan bahkan tidak ada suatu stimulus pun yang menjadi resiko terjadinya cedera. Hal ini mengindikasikan bahwa partisipan memiliki kecemasan terhadap adanya kemungkinan reinjury.

Perubahan fisiologis yang dapat terjadi akibat reinjury anxiety seperti ketegangan otot yang meningkat dan berkurangnya keseimbangan sebagaimana dicetuskan Heil (1993, dalam Walker et al., 2004) tidak terjadi pada seluruh partisipan. Namun terjadinya arousal yang berlebihan terjadi pada partisipan 01 dalam bentuk jantung yang berdegup lebih cepat saat hendak kembali berolahraga dan meningkatnya sensasi fisik dari sumber cedera terjadi pada partisipan 05 dalam bentuk sensasi rasa sakit yang semakin mudah terasa. Partisipan 03 tidak merasakan gejala somatis apapun ketika kembali lagi untuk berolahraga karena cedera yang dialaminya pun sudah membaik dan juga pada dasarnya partisipan menyukai olahraga tersebut. Adapun gejala somatis lainnya yang dirasakan oleh partisipan 02 adalah merasa tubuhnya kaget, lebih cepat lelah, dan kaku karena sudah lama tidak berolahraga. Rasa lebih cepat inipun dirasakan oleh partisipan 04. Sedangkan partisipan 06 merasakan tubuhnya menjadi 'ragu-ragu' ketika kembali lagi berolahraga. Untuk atlet yang kembali berolahraga dan berkompetisi setelah terjadinya cedera, reinjury anxiety dapat dimanifestasikan dalam beberapa cara, salah satunya adalah dengan membatasi intensitas dalam berolahraga. Hal ini terjadi juga pada partisipan penelitian ini yaitu partisipan no. 01, 02, 04, dan 05. partisipan 01 menyatakan bahwa dirinya tidak akan memforsir intensitas ketika berolahraga. partisipan 02 menyatakan dirinya akan mengomunikasikan rasa sakitnya ketika memang sakit tersebut terasa kembali. Pada partisipan 04, pembatasan intensitas latihan dilakukan ketika rasa sakit yang dirasakan kaki kanan sebagai kaki yang pernah mengalami cedera terasa kembali. Hal serupa juga terjadi pada partisipan 05 .

\section{SIMPULAN}

Penelitian ini menunjukkan adanya emosi-emosi negatif yang disertai dengan adanya gejala-gejala kognitif dan somatis yang muncul baik pada saat rehabilitasi maupun ketika kembali berolahraga pada atlet mahasiswa. Walaupun pada setiap partisipan emosi dan gejala-gejala yang muncul pun beragam, semua partisipan menunjukkan adanya gejala reinjury anxiety setelah cedera. Ketika diagnosa medis pun memperbolehkan mereka untuk kembali lagi berolahraga setelah rentang waktu rehabilitasi yang sudah ditentukan, atlet mahasiswa masih tetap merasakan kecemasan-kecemasan mengenai kemungkinan cedera kembali pada lokasi tubuh yang sama seperti cedera sebelumnya. Reinjury anxiety ini pun kemudian mempengaruhi perilaku-perilaku atlet ketika kembali berolahraga, misalnya dengan adanya pembatasan frekuensi dan intensitas olahraganya itu sendiri.

Cedera adalah konsekuensi negatif yang pasti 
dimiliki oleh semua atlet. Tak dapat dipungkiri bahwa aspek psikologis pun turut terlibat setelah terjadinya cedera, salah satunya adalah reinjury anxiety. Dibutuhkan langkah lebih lanjut untuk menanggulangi reinjury anxiety ini sendiri dikarenakan adanya pengaruh dari reinjury anxiety yang cukup besar terhadap performa atlet setelah mengalami cedera. Disamping itu, diperlukan langkah antisipatif untuk meminimalisir kejadian cedera pada setiap atlet.

\section{DAFTAR PUSTAKA}

APA. (2015). APA Dictionary of Psychology. (G. R. VandenBos, Ed.). Washington DC: American Psychological Association.

Arvinen-Barrow, M. (2014). The Psychology of Sport Injury and Rehabilitation. The Psychology of Sport Injury and Rehabilitation. https://doi. org/10.4324/9780203552407

Callen, M. C. (2015). Reinjury Anxiety \& Return-tosport Outcomes in College Students. 2.

Cassidy, C. M. (2006). Development of a measure of sport injury anxiety: The Sport Injury Appraisal Scale. Dissertation Abstracts International Section A: Humanities and Social Sciences, 1-1267.

Etzel, E. F. (2006). Understanding and Promoting College Student-Athlete Health: Essential Issues for Student Affairs Professionals. Naspa Journal, 43(3), 518-546.

Ford, J., Ildefonso, K., Jones, M., \& Arvinen-Barrow, M. (2017). Sport-related anxiety: current insights. Open Access Journal of Sports Medicine, 8, 205-212. https://doi.org/10.2147/oajsm.s125845

Hagglund, M., Walden, M., Bahr, R., \& Ekstrand, J. (2005). Methods for epidemiological study of injuries to professional football players: developing the UEFA model, 340-347. https://doi. org/10.1136/bjsm.2005.018267

Heil, J. (1993). Psychology of sport injury. Champaign,
IL: Human Kinetics. Illinois: Human Kinetics.

Hsu, C.-J., Meierbachtol, A., George, S. Z., \& Chmielewski, T. L. (2017). Fear of reinjury in athletes: Implications for rehabilitation. Sport Health, 9(2), 162-167.

Kleinert, J. (2002). An approach to sport injury trait anxiety: Scale construction and structure analysis. European Journal of Sport Science, 2(3), 1-12. https://doi.org/10.1080/17461390200072305

Putukian, M. (2015). The psychological response to injury in student athletes : a narrative review with a focus on mental health. Br J Sports Med, 0, 1-5. https://doi.org/10.1136/bjsports-2015-095586

Rotella, R. J., \& Heyman, S. R. (1993). Stress, Injury and The Psychological Rehabilitation of Athletes. Mayfield, Palo Alto, CA.

Wadey, R., Podlog, L., Hall, M., Hamson-utley, J., Hicks-little, C., \& Hammer, C. (2014). Reinjury Anxiety, Coping, and Retum-to-Sport Outcomes: A Multiple Mediation Analysis, 59(3), 256-266.

Wadey, R., Podlog, L., Hall, M., Hamson-Utley, J., Hicks-Little, C., \& Hammer, C. (2014). Reinjury anxiety, coping, and return-to-sport outcomes: A multiple mediation analysis. Rehabilitation Psychology, 59(3), 256-266. https://doi.org/10.1037/ a0037032

Walker, N., Thatcher, J., Lavallee, D., \& Golby, D. (2004). The emotional response to athletic injury: Reinjury anxiety. In Coping and emotion in sport (pp. 87-99). New York: Nova Science.

Walker, Natalie, \& Thatcher, J. (2012). The Emotional Response to Athletic Injury: Re- Injury Anxiety. In Routledge Online Studies on the Olympic and Paralympic Games: Book Chapters (pp. 37-41). https://doi.org/10.4324/9780203852293

Walker, Natalie, Thatcher, J., \& Lavallee, D. (2010). A preliminary development of the Reinjury Anxiety Inventory (RIAI). Physical Therapy in 